\title{
An island of civilization in a sea of delay? Indifference and fragmentation along the rugged shorelines of Kiev's newbuild archipelago
}

Authors: Kostyantyn Mezentsev, Michael Gentile, Nataliia Mezentseva, Iuliia Stebletska

Paper published in Journal of Urban Affairs

DOI: https://doi.org/10.1080/07352166.2018.1503544

Web link: https://www.tandfonline.com/doi/full/10.1080/07352166.2018.1503544

\section{Introduction}

Recent advances within gentrification theory suggest that gentrification is an inherent, global, feature of the neoliberal city (Slater 2017). Like neoliberalism itself, it assumes different forms in different contexts, but it nevertheless remains true to its mission: the class remaking of the city (Davidson 2018). In order support such a claim, the conceptual and geographical domains of gentrification theory have expanded considerably during recent years, partly due to Neil Smith's (2002) characterization of gentrification as a global urban strategy, and partly due to gentrification's increasing conceptual "sprawl" into adjacient themes within urban studies (Smart and Smart 2017). The latter includes the construction of newbuilds in urban non-fringe locations, which the concept of gentrification has arguably englobed as yet another expression of the wholesale remaking of the city under neoliberalism. Like gentrification itself, newbuild gentrification (NBG), as this phenomenon has come to be known, has a rather elastic and highly contested definition, spanning from what essentially amounts to a denial of its existence (Boddy 2007), to a process that may involve "swathes of disused brownfield sites" (Davidson and Lees 2005: 1170). Central to any definition of gentrification is whether and to what extent displacement - direct or indirect - is taking place. In most instances of NBG, displacement can only be indirect via price shadowing effects (Boddy 2007), although recent work based in non-Western contexts demonstrates its association with widespread direct displacement via the demolition of low-rise, often informal, dwellings and their 
replacement by high-rise, formal and higher-status, condominiums (Harris 2008, Shin 2016). Some scholars, however, argue that displacement should also be understood as a form of phenomenological dispossession, as a loss of neighbourhood place induced by gentrification (Davidson and Lees 2010). While gentrification (research) has gone global, most influential theories of gentrification remain heavily reliant on classic cases, particularly New York, London, Amsterdam and Berlin, prompting the critique that the concept's hegemony, protected by Anglophone gate-keepers, silences alternative explanations of displacement, forcing the gentrification framework, disguised as "international" theory (Cartier 2017), on situations where there already exist suitable alternative perspectives (Smart and Smart 2017). Thus, when gentrification theories imported from the global northwest are put to test in the peripheries of urban theory, the evidence points towards the need for revisions, refinement, adaptation, contextualization or even outright rejection, confirming what Lees (2012) noted some years ago, i.e., that we should not read gentrification in the South (or anywhere else) as a recreation of the patterns in the "supposed centre". For example, Ghertner (2015) suggests that gentrification fails in much of the world owing to the predominant worldwide absence of Western-style property and tenure rights.

The effects of gentrification on the social characteristics of place remain at the core of the research endeavor. "Classic" gentrification as described in most research conducted until the turn of the millennium is a gradual process of urban socio-spatial transformation leading to the erosion of existing neighbourhood community structures because of the characteristics and preferences of the newcomers (Dangschat 1988). NBG is claimed to have similar effects, but with a sudden forward-going time warp: newbuilds are frequently large developments that bring many new residents and much fresh capital into a specific area within a relatively short period (Davidson and Lees 2005). Hence, for much of the burgeoning literature on this topic - at least within the "critical" strand - the social consequences of NBG are a matter of great concern, and the impact of NBG on the local social milieus which it comes in contact with is often assumed to be toxic (Davidson 2008, 2010; Uitermark et al. 2007). Moreover, newbuild developments are sometimes seen as the main vehicle carrying the gentrification germ from the areas of initial localized infection to the rest of the city, resulting in a developer-induced wholesale 
colonization of urban space (Davidson 2007). In other words, a global brand of gentrification is spreading its tentacles across urban space, increasingly decoupling and distancing itself from local context; in the process, it is often supported by state or municipal authorities, e.g., in the guise of social mixing policies (Lees 2008, Davidson 2010), slum clearance (Nagy and Timár 2012, Choi 2016) or urban regeneration (Smith 2002, Harris 2008).

In the light of the above, it is argued that there is a need for a more globally inclusive empirical engagement with NBG and with its social consequences at the neighbourhood level. While the more general question arising from the "gone-global" (or planetary) thesis is whether or not newbuild developments really are colonizing urban space to the extent that some claim they are doing (see, e.g., Smith 2002, Davidson 2007, Davidson and Lees 2010), the impact they have on the neighbourhoods targeted by them has become the main focus of attention during recent years, especially in regard to the issue of the link between NBG and (indirect) displacement (cf. Boddy 2007 and Davidson and Lees 2010). Moreover, because displacement in the traditional sense is not easily demonstrated (newbuilds often appear on vacant plots, including brownfields), a case has been made for a phenomenological understanding of displacement that emphasizes how NBG dissolves place, the multitude of local assets and relations having ripened over the long-term, and which form the basic structure of the local community (Davidson 2008, Davidson 2010, Davidson and Lees 2010, Stabrowski 2014). Accordingly, areas infected by NBG become "colonized and unfamiliar" (Davidson 2010, p. 540); the degree to which such feelings prevail is presumably related to the extent and nature of the social contacts and connections that evolve - or fail to evolve - between newbuild gentrifiers and the long-term residents of the neighbourhood. It is these contacts that are at the core of this paper.

We explore how the social environment evolves in areas that have experienced the arrival of significant newbuild developments. Based on in-depth interviews with newbuild gentrifiers and "locals", as well as on the analysis of contributions to relevant web-based fora, we investigate how and to what extent the residents of the newbuilds interact with the "indigenous" neighbours, the two groups' mutual perceptions of one another, and the locals' assessment of the effect of the newbuilds on the 
quality and living conditions in their neighbourhoods. Our field setting consists of two neighbourhoods in Kiev, a major European metropolis which has experienced a substantial growth in new residential construction during the past few years. The first neighbourhood is Sotsgorod ("Socialist city"), and the second neighbourhood is "Comfort Town" (CT), a gargantuan, colourful, but only mildly gated estate that has "landed" on an adjacient brownfield.

\section{Newbuild gentrification and its social contours}

The literature on the effects of NBG is a bit ambivalent: on the one hand, there are studies, particularly from London, that indicate that newbuilds contribute to indirect as well as to direct displacement, causing substantial harm to local communities. On the other hand, different indications have been found elsewhere, specifically that "locals" have mixed feelings about NBG, plus that they tend to stay put. Similar contradictions are well documented in the literature on traditional forms of gentrification, which is somewhat polarized on this issue - between critical and "less-than-critical" standpoints (exemplified in exchanges between Slater 2006 and Freeman 2008 in the International Journal of Urban and Regional Research, and between Slater 2009 and Hamnett 2009 in City).

The relevant literature on the community effects of NBG is concentrated within three main inter-connected strands. The first one is the established literature on the impacts of gentrification on local communities and on the evolution of social contacts and ties at the neighbourhood level; this literature has developed over approximately half a century, centering on displacement as the main force lying behind community disintegration, and despite its relevance, it is beyond the scope of this paper to rehearse this very extensive material. The second strand, which we review more carefully below, is the NBG literature in itself, which discusses the process' social consequences when direct displacement is absent (as it usually is in Western contexts), and which also includes the relevant sections of the literature on brownfield regeneration. The third strand relates to the impact of social mixing policies, which often include NBG as active ingredient, with the increasingly challenged assumption that socially heterogeneous communities are, overall, stronger and healthier than homogenous ones. Moreover, 
because newbuild developments are often - or tend to become - gated and guarded, a useful complement to these three strands of the literature is the body of research on gated communities. In most of Central and Eastern Europe (CEE), decades of state socialist urban government have meant that gentrification typically must start in areas with an existing social mix, areas in which one would expect to find representatives of most social groups. Also, while the literature suggests that the community impact of this initial social mix might be ambiguous, an additional important characteric that sets apart most cities in CEE is the residential immobility (particularly in high-rise housing estates) caused by the demised socialist system of administrative housing allocation, which meant that families who received an apartment were expected to live there for rest of their lives (Gentile and Sjöberg 2013). Therefore, it may be assumed that residents of CEE cities are more attached to their homes and neighbourhoods than what might be the case elsewhere.

Long considered an anomaly in the urban socio-spatial structure of a limited sub-set of (global) cities, gentrification started to become more widespread until it was temporarily slowed down by the recession of the early 1990s. By the time most Western economies recovered, the stage was set for gentrification to regain momentum in what soon came to be known as "the third wave" of gentrication (Hackworth and Smith 2001, Smith 2002). As a result, the long-lasting decline of the inner city areas of North-American and (many) West European cities came to a halt, and in some cases it was even reversed, and often dramatically so. Underlying this change is a combination of changed cultural preferences, (second) demographic transition, and the maturity of rent gaps - three aspects that have been at the centre of much controversy in gentrification research since the 1980s (Buzar et al. 2007, Rérat 2012b).

Third wave gentrification is said to involve the expansion of gentrification beyond its traditional inner city confines, often as part of urban regeneration or neighbourhood renewal strategies orchestrated in tandem by developers and public sector actors (Smith 2002). NBG is an important part of this process, and although the G in NBG has been challenged on the basis that newbuild development typically occurs on previously non-residential land, meaning that direct displacement is unlikely (Boddy 2007), there is little doubt that it is one of the principal expressions of the deep-going transformations 
that cities have been experiencing since the onset of the new millennium. Newbuild developments may crop up on former brownfields, on vacant or underdeveloped plots in residential or functionally mixed neighbourhoods, along waterfronts, as vertical extensions of existing buildings, on top of or instead of existing transport infrastructure, as well as through the demolition and replacement of existing housing stock. Similar to NBG in terms of its outcome is the functional conversion of commercial or office space to residential use (see e.g. Visser and Kotze 2008), i.e., residentialization (Haase et al. 2010) - a term that particularly angers critical scholars such as Wacquant (2008), Smith (2002) or Davidson and Lees (2010), who see it a deceitful euphemism that "sugarcoats" (Smith 2002) gentrification.

Newbuilds often come with eye-catching architecture that imprints a mark of distinction within the cityscape (Andersen and Røe 2016), responding to the "global" lifestyle preferences of the expanding class of professionals (Davidson 2007) and, to use Richard Florida's (2003) language, of its "super-creative core". The residents of newbuilds tend to be young and relatively affluent (Davidson 2007), although Rérat's (2012a) study in the Swiss cities of Zurich and Neuchâtel suggests that the higher prices of newbuilds vs. existing stock tend to exclude the younger segment of gentrifiers, who typically have less starting capital (see also Rérat et al. 2010). Rérat (2012a, 2012b) also suggests that NBG be placed within a life course perspective, and that the gentrifiers appear to be "stayers", rather than newcomers to the inner city, who are motivated by the comfort of inner city life. Boterman et al. (2010) propose that these stayers - a small but increasing segment of the middle class in Amsterdam - are motivated by the experience accumulated during prolonged periods of urban life before getting children (see also Lilius 2014).

NBG outside of the major cities of the north-western quadrant of the world map has only recently appeared on the agenda of gentrification scholarship, even though there is plenty of evidence that it has been around for quite some time, and in forms that are not always reminiscent of the patterns identified within the main bastions of theory-generation (Lemanski 2014, López-Morales 2015, Shin and Kim 2016). In particular, the preponderance of large-scale slum-clearance and urban regeneration programmes, e.g., in connection with mega-events (see e.g. Davis 2011, Gaffney 2015), encouraged Lees 
to denounce the "visceral emergence of state-led gentrification in the Global South" (Lees 2012, p. 156). There is also a narrative of colonization-by-gentrification, whereby rent gaps nowadays emerge at the global (or "planetary") level (Slater 2017, Sigler and Wachsmuth 2016) in response to tourist flows, transnational speculative real-estate investment (money parking within real estate) or investment by diaspora communities in housing "back home" (Gentile et al. 2015, Goodfellow 2017). In most cases, the state is involved, even though the degree of its involvement may range from tacit complicity (Gentile et al. 2015) to full control over the process (Valiyev 2013), and from softening (Rose 2010, Hochstenbach et al. 2015) to "hardening" agent (Kovács et al. 2013). In sum, it may be said that NBG or NBG-esque phenomena are an increasingly global trend with local specifics.

At this point, it becomes imperative to note how NBG plays out in very different ways across different contexts. With the notable exception of an early study on Vancouver (Mills 1988), the NBG literature's initial anchors were the cases of a handful of global cities that are not representative of the "rest", even though the urban studies literature has tended to treat them as if this were the case (Robinson 2011, p. 10). When NBG lands on other sites, its effects may differ substantially from those observed; for example, Doucet et al. (2011, p. 1411) note that the setting for NBG (or any gentrification) is radically different in old industrial cities than in global cities, to which the pool of potential gentrifiers is attracted naturally. Another limitation to gentrification in non-global cities was noted by Bridge (2006), whose research in Bristol recognized that (p. 1967) "the temporal process of intergenerational reproduction via institutionalized cultural capital trumps the spatialized aesthetic, indicating the limits of the gentrification habitus and a more conventional middle-class path through the city to the (educationally) safe suburbs". In other words, unlike in London, where the gentrifiers are able to form a critical mass that is also able to "gentrify" schools (Butler and Robson 2001), gentrification lower down the urban hierarchy struggles to maintain a population of permanent residents, despite indications that gentrifiers in these cities may be bringing the newbuild gentrifier "global" lifestyle with them upon returning from a career-related stay in a global city (Dutton 2003). The same is of course true for the categories known as marginal (Rose 1984, van Criekingen and Decroly 2003) or apprentice gentrifiers 
(e.g., students)(Smith and Holt 2007), who often cluster in the inner city because of a combination of lifestyle preferences and economic advantages, arguably making a greater contribution to reurbanization rather than to gentrification (Buzar et al. 2007, Kovács et al. 2013). Unlike the former, the latter are unlikely to contribute to the direct regeneration of the housing they occupy as they tend to live in shared apartments on a low budget and with transitory arrangements (Haase et al. 2012), even though purposebuilt student newbuild housing is increasingly challenging this tradition (Sage et al. 2012, Smith and Hubbard 2014).

Important contextual differences also emerge within the temporal dimension. Gentrification is traditionally conceptualized as an evolutionary process that can be described using phase (or wave) models (Dangschat 1988, Hackworth and Smith 2001), with the wave "model" being the most influential, having spurred a torrent of papers on, e.g., "second" (e.g., Bounds and Morris 2006) or "third" (e.g., Murphy 2008) wave generation. However, the linearity of the process was soon to be put into question by research that focuses on the non-Anglo-American experience of gentrification (van Criekingen and Decroly 2003). In CEE, for example, the three waves appear to be compressed and independent from one another, meaning that gentrification simultaneously unites different types of processes which have different intensities depending on context (Kovács et al. 2013, Holm et al. 2015, Bernt 2016). NBG in this region is thus not preceded, but accompanied by trends that are characteristic of the "first" and "second" waves, of which there were few signs until the mid-2000s (Sýkora 2005); prominent reasons include the unclear property rights situation in several countries, restitution policies, the absence of a long-term mortgage market (until the early 2000s in some countries, still today in others), the only recent emergence of a "post-socialist" middle class of professionals, and the preponderance of owner-occupation. In addition, land in "post-socialist" cities was characterized by a very high share being used for industrial purposes (Bertaud 2006, Gentile and Sjöberg 2006), nowadays available as brownfield material, the removal of which opens up for the exploitation of substantial rent gaps.

As Bryson (2013, pp. 583-584) notes, the impact of brownfields in shaping the preconditions for gentrification (i.e., the rent gap) requires greater attention. In particular, when a brownfield 
is redeveloped, the land value of the surroundings may be expected to rise, with a concomitant expansion of the rent gap, catalyzing redevelopment, gentrification and, ultimately, "price shadowing" (Atkinson 2000) there too. A similar spillover effect has been identified in relation to flagship projects, as well as to smaller localized transformations. Temelová (2007) found that the Golden Angel project (a creation by celebrity architect Jean Nouvel) in Smíchov, Prague, initiated a moderate regeneration process radiating from the project itself, which added on to the gentrification pressure that was emanating from the city centre, which is located on the opposite side of the neighbourhood. Old working-class Smíchov was being attacked on two fronts, a battle which it seemingly has lost (Temelová and Dvořáková 2012). At a smaller scale, Anguelovski (2015) emphasized that the arrival of a new retail facility (displacing an old one), specifically a Whole Foods grocery store, has an immediate effect on the surrounding property values, accelerating gentrification, transforming the local community, eroding social cohesion, and ultimately causing displacement. The latter effect has become so characteristic of contemporary gentrification in the US that the iconic South Park cartoon focused the entire 2015 season on gentrification-by-Whole-Foods.

Despite these effects, research on the effects of gentrification, and particularly of NBG, on local community remains inconclusive and contradictory, not least because the opinions and perceptions of local non-displacees are often forgotten in debates on the winners and losers of gentrification (Doucet 2009), and because the experiences of displaced leavers - a population which is difficult to reach - are understudied (Freeman and Braconi 2004). For Davidson (2008), the ambiguity of this situation is an illusion, for any initial welcoming of gentrification cools down as soon as its negative consequences emerge into sight, and evaporates when these consequences accelerate. However, other views challenge Davidson's assumption. Doucet's (2009) study of the experiences of non-gentrifiers in a gentrifying area of Edinburgh reveals mixed opinions and "a striking lack of major critical remarks" (p. 312), despite the fact that the process had been going on for a long time. Similarly, neither Freeman $(2006,2008)$ in the United States nor Kovács et al. (2013) or Sagan and Grabkowska (2012) in Hungary and Poland, respectively, find any expressions of severe discontent. 
Lack of severe discontent, however, is not the same as saying that gentrification and social mix bring warm and intense social contact. In fact, while the evidence is again rather mixed, it appears that the effects of gentrification and of overt policies aimed at achieving socially mixed (or "balanced") communities on neighbourhood-level social relations are frequently offset by other more powerful influences, including the characteristics of neighbourhood inner design and layout (Kleinhans 2004), as well as the tendency among gentrifiers to "pad the bunker" and shut themselves off from the immediate surroundings (Atkinson 2006). Indeed, the extant empirical research indicates that gentrification does not increase social contact beyond the most superficial level. Butler and Robson's (2003) research on London suggests that social cohesion is more likely in socially homogenous areas (see also Cheshire 2006), while Freeman's (2006) work on New York reveals little actual interaction between social classes in gentrified areas. However, there also exist studies that suggest otherwise: Sagan and Grabkowska (2012, see also Grabkowska 2015), for example, offer a more positive assessment based on their research in Gdańsk, which shows that the gentrifiers are well aware of the local social context, and that they even contribute with new ideas in regard to neighbourhood renewal, influencing the opinions of the established residents. Even more positive is the verdict by Hiob et al. (2012), who claim that gentrification has enabled an old neighbourhood in the Estonian city of Tartu, an area which was literally doomed, to "rise from the dead" and become a "bustling community" (although it is unclear to which extent this community includes non-gentrifiers).

Despite this note of optimism, the overarching narrative in research on social contacts between gentrifiers and stayers is negative. Davidson (2010, p. 532) concludes that spatial proximity has failed to foster mixing in the London Thamesfront newbuild areas; among other things, the availability of in-house services in newbuild developments limits the demand for local services. Similarly, Butler (2007) showed that the typical (affluent) resident of the Docklands development is completely uninterested in the immediate neighbourhood because his or her social networks largely link to the workplace, while Marquardt et al. (2012, p. 1541) indicate that luxury new-build developments are described as both urban at heart and protected from the negative externalities present in central Berlin. 
Predictably, in Marquardt et al.'s study (2012), the newbuild gentrifiers do not seem to have much contact with their surroundings either. And in Butler's (2007) case, the Docklands are described as a "suburbia for singles and empty nesters" (p. 777), who value safety and proximity to the city, without the disadvantages. As a result, he concludes that the Docklands represent a form of voluntary incarceration in the city, an incarceration that is not unlike the one experienced by or imposed upon the residents of gated communities across the world (Atkinson 2006, Lemanski 2006). Alternatively, it could be seen as a form of spatial secession from the city on behalf of the affluent (Hirt 2012).

Davidson (2007) submits that it is the supply side - architects, developers and aggressive marketing - that creates social distance, concluding that "gentrification [...], and its connections to globalization, are therefore less a sociological coping strategy or form of class reproduction and more as a capital-led colonialization of urban space with relations to globalization in terms of architectural design, investment strategies, social-cache-boosting marketing strategies and 'non-local global' lifestyles" (p. 493). Accordingly, different gentrification schemes - diverse as they may be on surface - are likely to make reference to global narratives (ibid., p. 494) or, as we shall see below, to other geographical narratives that are relevant in specific contexts.

The fact that there seems to be little interaction and social cohesion between the residents of newbuild developments and their “indigenous” neighbours lends credibility to Davidson's (2008, see also Davidson and Lees 2010) suggestion that NBG causes displacement understood as the erosion of place. Based on multiple survey data, Tolsma et al. (2009, p. 301) attribute this lack of social cohesion not to social (or ethnic) heterogeneity per se, but to the finding that the highly educated are less likely to engage in neighbourly contact within a context of neighbourhood economic heterogeneity; put differently, gentrifying newcomers, who are often warmly welcomed by policy-makers looking for a healthy social mix (van Kempen and Bolt 2009), simply do not mix. Instead, such social mixing by gentrification appears to break down the advantages of neighbourhoods with similar populations, eroding mutual support networks (Cheshire 2006), and causing cultural, political and, ultimately, community displacement (Hyra 2015). Finally, as Davidson (2008) fears, there is the risk that newbuild gentrifiers would consider moving 
into surroundings neighbourhoods (rather than suburbanizing) on the occasion of life-stage changes. This would mean that initial non-displacement could be followed by real displacement, not only through price shadowing effects, but also as a result of the spillover of newbuild gentrifiers into the surrounding areas.

In sum, while NBG has received very much attention over the past few years, the characteristics of the process, and its consequences for the communities influenced by it, are still subject to much debate. To some degree, this debate is of a theoretical or conceptual nature: Is this gentrification, does gentrification theory help us make sense of newbuild developments during the era of neoliberalism? To an even greater degree, however, the debate is of an empirical character: Is NBG "colonizing" urban space, are people actually being displaced, are communities being ruptured, do residents of newbuild developments interact with their "indigenous" neighbours (and vice versa), how do locals and newbuild newcomers view one another, and how do they perceive and interpret their respective living environments? This paper engages with this second set of questions, and particularly with the latter three. 


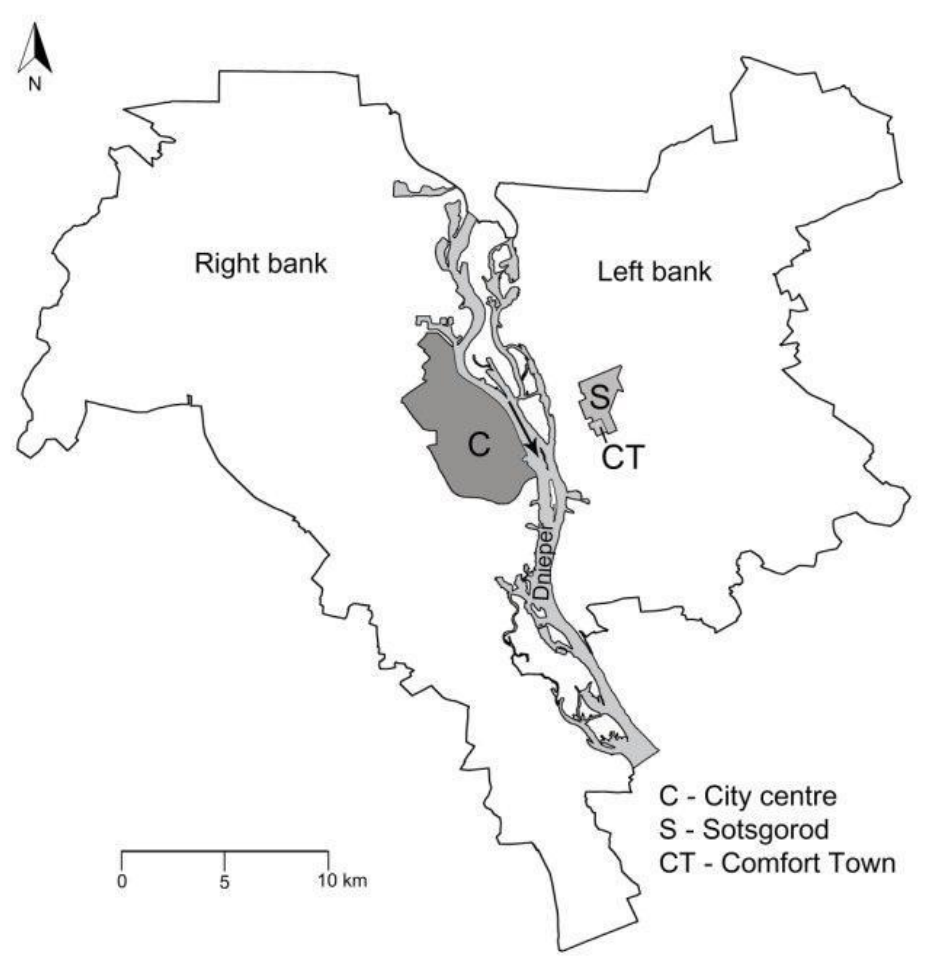

Figure 1

\section{Data and methods}

The Kiev gentrification research setting differs in a number of important ways from the Western European or North American case. First of all, unlike in London or Berlin, gentrification is not a "dirty word" (Smith 1996: 28), and in fact, it is hardly a word at all - only certain specialists would have heard of the professional niche concept of dzhentryfikatsiya (Ажентрифікація). Second, there is a tradition of little resistance to urban transformation processes, which stems from the fact that urban planning issues were not subject to public scrutiny under Soviet times (urban planning documents and decisions were "for official use only", i.e., secret). Third, a very high share of the housing stock is owner-occupied, reducing the risk of direct displacement, even though, as one would expect in a consolidating market economy, the private rental market is steadily growing. Fourth, newbuild developments in Kiev come against the background of the suppressed housing demand that had characterized the Soviet period, 
coupled with the widespread perception that real estate is the only safe investment amidst the insecurity of the crisis-prone Ukrainian economy, leading to speculation. Finally, the Soviet housing stock, which was poorly built from the beginning, is rapidly decaying, creating an additional need for new housing. ${ }^{1}$ These characteristics of the Kievan research setting largely resemble those that one would expect to find elsewhere across the countries that once formed the Soviet Union.

Our work is based on two Kievan related case study areas: Sotsgorod ("Socialist city", "Sotsmisto" in Ukrainian) and Comfort Town (Figure 1). Sotsgorod is a socially mixed Soviet-era neighbourhood built from the late 1950s until the early 1970s (Figure 2a) on the less prestigious left bank of the Dnieper; most of its residents (or their parents or grandparents) were allocated their apartments free of charge during the Soviet period (until 1991) and consider market-based housing allocation as inherently unjust (cf. Zavisca 2012). Sotsgorod has recently attracted a number of small, mid-sized and, increasingly, large-scale newbuild developments (Figure 2b). A characteristic feature of the Sotsgorod neighbourhood is its proximity to extensive industrial areas, most of which now brownfields that are or could be available for land recycling. Comfort Town is built on such a former brownfield, on the site of the demised "Vulkan" rubber regeneration factory, which produced shoe components (e.g., soles, heels) out of recycled rubber from old tyres. With approximately 7000 apartments (LUN 2018), and thousands more planned for the future, Comfort Town is a master-planned settlement which is still under construction. It was transformed into a gated community of sorts not long after the first residents - who were not aware of the forthcoming gating - started moving in (Figure 2c). While the perimeter of the development is fenced and the main entrance guarded, it is relatively easy to enter unnoticed, especially during evening peak hours, when there is a constant flow of people who out of courtesy hold the small pedestrian gate open for the next person coming in (we tried getting in this way on various occasions and never failed). Moreover, it is also possible to rent rooms or apartments within the complex on a daily basis, e.g. via AirBnB or Booking.com, with no interference whatsoever from the developer or

\footnotetext{
${ }^{1}$ An additional local characteristic is the continued (albeit greatly reduced) tradition of employer-supplied housing. Some newbuild developments are thus built by ministries for the exclusive use of their employees.
} 
homeowner association (one of the authors rented an apartment for six days in April 2018 in order to gain better insights into life in the compound). The first apartments were delivered in 2010, and the project currently stands at stages 6 and 7 out of 7 . In line with the prevailing discourse of "Europe" as embodiment of modernity and comfort (Orlova 2017), the development's website markets the project as "Your Little Europe within the Kiev Mega[lo]polis", clarifying that it consists of "genuine low-rise European architecture" that evokes images of "small-town Flanders" and within which buyers could "live in a European manner already today" (Comfort Town 2018, authors' emphasis). And just to make sure that the message not be left unnoticed, the cover of the development's brochure encourages prospective buyers to "start [living] a European life". In other words, not only is the development "European", but it also brings the future into the present, consigning the rest of the city, and Sotsgorod in particular, to the past and to the elsewhere. Life in Kiev, as it were, is not life in Europe. Moreover, while the architectural Europeanness or Flemishness of the project may still be debatable, defining CT as a lowrise development clearly is a misnomer given that it consists of densely packed 5-16 storey buildings (Figure 2d), whereas the surrounding Soviet mikrorayony are generally far more spacious. In short, an imaginary European capitalism is juxtaposed and contrasted with the harsh realities of the socialist past in the present. Ironically, this all happens in "Regeneration Street" (Vulitsa Regeneratorna), an address that owes its name to the aforementioned "regeneration" activities of the Vulkan factory.

We use three main sources of information: (1) publicly available statistics on real estate transactions and wages for the initial presentation of the Kiev housing market, (2) thirteen in-depth interviews with residents of the two case study areas, and (3) entries concerning these two areas made in Kievan online real estate discussion fora by anonymous and identifiable contributors. In the discussion of the results, the online discussion forum entries are marked with an F, interviews conducted in Sotsgorod with an S, and interviews conducted in Comfort Town with a K. Combining the real estate discussion forum materials with interviews allows us to capture a greater spectrum of opinions and attitudes. The major benefit of the online fora is that they offer a "naturalistic" research environment which is not contaminated by the researcher's presence (Jowett 2015); the downside is 
that they tend to be characterized by an over-representation of socially undesirable or aggressive opinions, particularly when anonymity is allowed (Rösner and Krämer 2016). The interview materials are designed to (also) capture the opinions of the moderate mass, and the two sources are thus, to some extent, complementary. One specific advantage of using commentary in online fora is that, while often expressing polarized opinions, it allows the identification of the most topical issues in relation to the case study areas. This, in turn, is a useful source of information in view of the interviews.

The interviews covered several broad topics: the feeling of comfort in and overall (dis)satisfaction with the neighbourhood and its living environment, the interviewees' "rootedness" in the area, their assessment of the quality and sufficiency of the neighbourhood physical infrastructure (including public transportation), their opinion about CT (among Sotsgorod residents) and Sotsgorod (among CT residents), and environmental concerns. While the discussion within each of these topics was free, the interviewer ensured that certain specific questions were asked when they did not surface spontaneously. However, all respondents were asked one final question, i.e., whether they had ever heard about gentrification: no one had. 

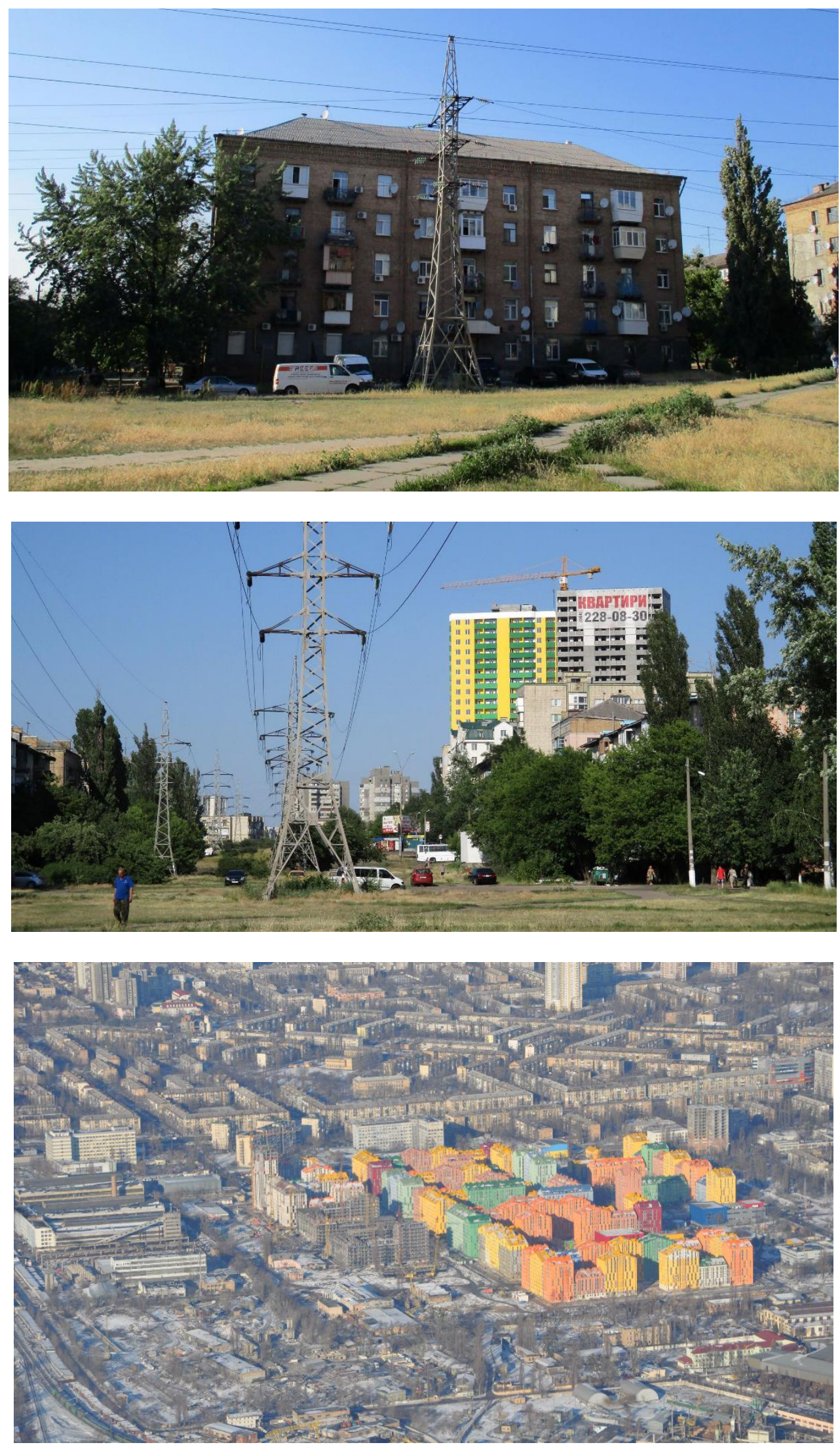


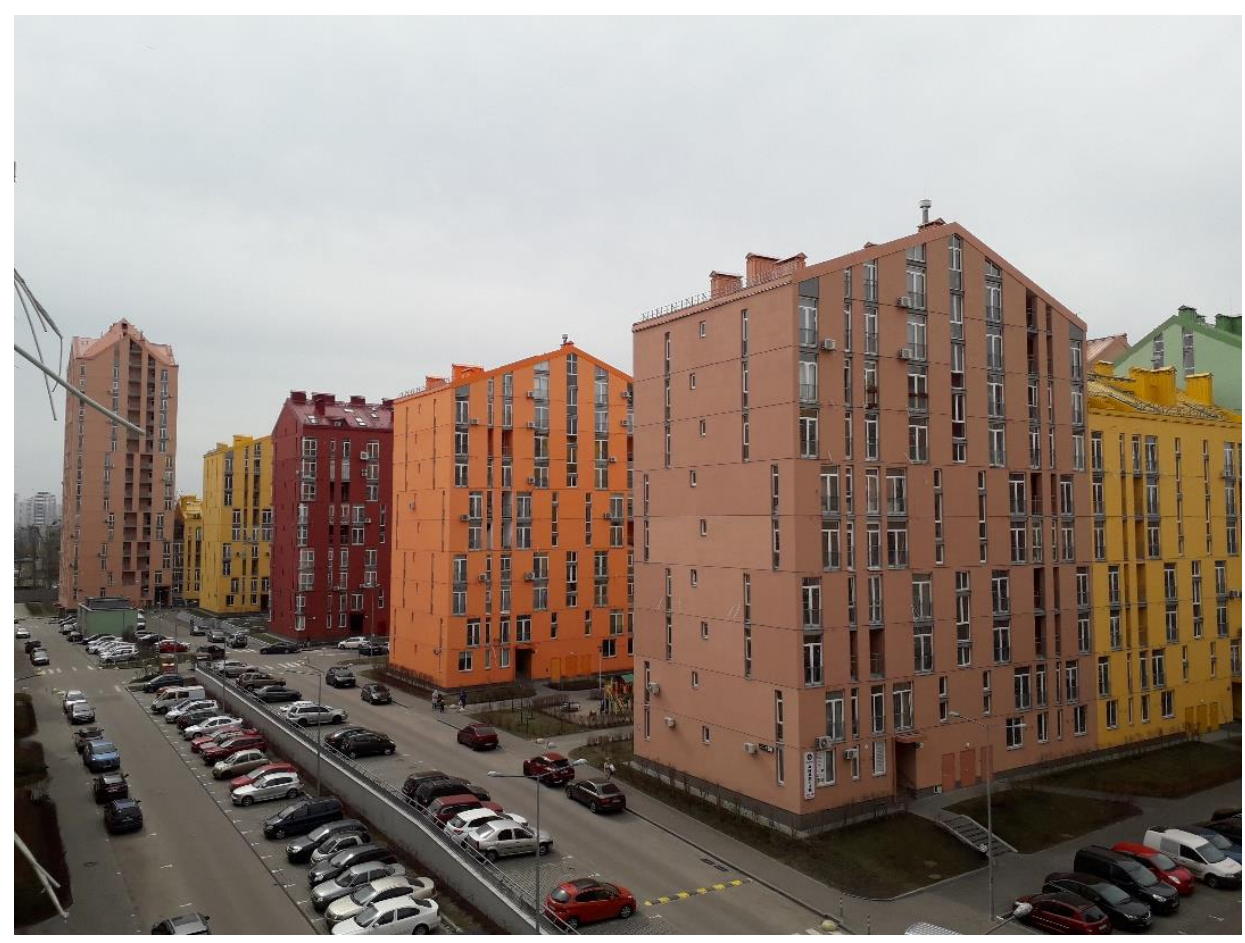

Figures $2 a-2 d$

\section{Kiev housing market context}

Kiev's housing market during the past decade has been highly volatile (Table 1a). In the three years before the 2008-2009 global financial crisis, which hit Ukraine particularly hard, square metre prices increased rapidly, reaching over $3500 \mathrm{USD}^{2} / \mathrm{m}^{2}$ overall and over $5200 \mathrm{USD} / \mathrm{m}^{2}$ in the city centre. Between 2008 and 2009, the USD price level dropped by 52\%, slowly rising thereafter until 2013, after which the postMaidan crisis dealt the next blow in the form of a new drop of $38.5 \%$ between 2013 and 2015 . Thus, the dollar price for one square metre of housing in Kiev in 2017 stood at a mere 32\% of the 2008 level. Traditionally, the right bank to left bank price ratio has fluctuated around 1.3. In terms of housing affordability (Table 1b), measured as the number of mean-income months needed to buy one square metre of housing, the 2008-2009 crisis translated into greater affordability, whereas the trend was moderately reversed during the post-Maidan crisis. However, these aggregate figures conceal the effect of the Ukrainian hryvna's (UAH) devaluation, which greatly reduced the purchasing power of those receiving their wages in the national currency, while increasing the purchasing power of hard currency

\footnotetext{
${ }^{2}$ In reality, as a result of the Ukrainian hryvna's tendency to devaluate, property prices are expressed in "conditional units", which is a euphemism for US dollars. This is quite typical in post-Soviet space.
} 
wage-earners. ${ }^{3}$ In fact, between 2013 and 2015, the dollar-equivalent of the mean monthly wage in Kiev dropped 627 to 308 USD (and from 408 to 192 USD in Ukraine, calculated from Derzhavna 2017). In this respect, it should be noted that a hard currency wage is per definition a regularly paid illegal bonus since all legal - and taxable - income must be in national currency. Figure 3, which reports the square metre prices for new apartments in the broader Sotsgorod area (including CT) between 2010 and the first quarter of 2018, illustrates this contradictory trend: in just a few years, USD-prices halved, whereas UAHprices nearly doubled (this was after a 30\% drop in prices during the first quarter of 2009, a few months after the peak of a 2006-2008 real estate bubble, when the square metre prices in the wider Sotsgorod area reached past 2750 USD). The difference was particularly dramatic between 2012 and 2016. Starting from mid-2016, the development of USD and UAH prices has been similar(ly negative), reflecting the recent stability of the exchange rate. Importantly, in addition to popping the aforementioned real estate bubble, the global financial crisis of 2008-2009 effectively extinguished the nascent mortgage market; instead, developers resorted to different types of short-term amortment schemes (e.g., construction bonds, installments) (Galitskaya 2013, Osipova 2013); one of the most flexible actors in this respect is the developer of CT, KAN Development, which was particularly active in devising "anti-crisis measures" to soften the effects of the UAH devaluation on buyers who had taken loans in hard currency (Comfort Town 2018).

Table 1a: Nominal square metre prices for apartments in Kiev in conditional units (USD), 2006-2017.

\begin{tabular}{|l|l|l|l|l|l|l|l|l|l|l|l|l|l|}
\hline $\begin{array}{l}\text { Nominal square metre prices in } \\
\text { "conditional units" (USD) }\end{array}$ & $\mathbf{2 0 0 6}$ & $\mathbf{2 0 0 7}$ & $\mathbf{2 0 0 8}$ & $\mathbf{2 0 0 9}$ & $\mathbf{2 0 1 0}$ & $\mathbf{2 0 1 1}$ & $\mathbf{2 0 1 2}$ & $\mathbf{2 0 1 3}$ & $\mathbf{2 0 1 4}$ & $\mathbf{2 0 1 5}$ & $\mathbf{2 0 1 6}$ & $\mathbf{2 0 1 7}$ & $\begin{array}{l}\mathbf{2 0 1 7 / 2 0 0 8} \\
\mathbf{( \% )}\end{array}$ \\
\hline Kiev & 2243 & 3239 & 3517 & 1691 & 1751 & 1808 & 1863 & 1940 & 1477 & 1193 & 1170 & 1125 & 32.0 \\
\hline City centre & 3291 & 4709 & 5240 & 2822 & 2786 & 2745 & 2926 & 2989 & 2259 & 1800 & 1778 & 1728 & 33.0 \\
\hline Right bank & 2404 & 3505 & 3818 & 1837 & 1889 & 1916 & 1991 & 2064 & 1902 & 1267 & 1247 & 1203 & 31.5 \\
\hline Left bank & 1818 & 2566 & 2795 & 1310 & 1392 & 1459 & 1521 & 1595 & 1228 & 1004 & 979 & 935 & 33.5 \\
\hline Right/left bank price ratio & 1.32 & 1.37 & 1.37 & 1.40 & 1.36 & 1.31 & 1.31 & 1.29 & 1.55 & 1.26 & 1.27 & 1.29 & \\
\hline
\end{tabular}

Source: apartment price transaction data from SV Development (2018), accessed 28 April 2018.

Table 1b: Monthly wages needed to buy one square metre in an apartment in Kiev, 2006-2016.

\begin{tabular}{|l|l|l|l|l|l|l|l|l|l|l|l|}
\hline Monthly wages needed to buy $1 \mathbf{~ m}^{2}$ & $\mathbf{2 0 0 6}$ & $\mathbf{2 0 0 7}$ & $\mathbf{2 0 0 8}$ & $\mathbf{2 0 0 9}$ & $\mathbf{2 0 1 0}$ & $\mathbf{2 0 1 1}$ & $\mathbf{2 0 1 2}$ & $\mathbf{2 0 1 3}$ & $\mathbf{2 0 1 4}$ & $\mathbf{2 0 1 5}$ & $\mathbf{2 0 1 6}$ \\
\hline Kiev & 6.52 & 7.12 & 6.04 & 4.16 & 4.03 & 3.59 & 3.23 & 3.08 & 3.27 & 3.87 & 3.46 \\
\hline City centre & 9.57 & 10.35 & 9.00 & 6.95 & 6.42 & 5.45 & 5.07 & 4.75 & 5.01 & 5.84 & 5.26 \\
\hline Right bank & 6.99 & 7.70 & 6.56 & 4.52 & 4.35 & 3.80 & 3.45 & 3.28 & 4.22 & 4.11 & 3.69 \\
\hline Left bank & 5.28 & 5.64 & 4.80 & 3.23 & 3.21 & 2.90 & 2.64 & 2.54 & 2.72 & 3.26 & 2.90 \\
\hline
\end{tabular}

${ }^{3}$ The mean 2013 UAH/USD exchange rate was 7.99, whereas it was 21.84 in 2015, and 26.31 in June 2017. It has remained stable at around 26-27 UAH/USD since then. 
Source: calculated based on wage statistics for the city of Kiev (Derzhavna 2017) and apartment price transaction data from SV Development (2018), both accessed 28 April 2018.

Table 1c: Nominal square metre prices for newbuild apartments in Kiev in conditional units (USD), $2006-2017$.

\begin{tabular}{|l|l|l|l|l|l|l|l|l|l|l|l|l|}
\hline $\begin{array}{l}\text { Nominal square metre prices in } \\
\text { "conditional units" (USD) }\end{array}$ & $\mathbf{2 0 0 6}$ & $\mathbf{2 0 0 7}$ & $\mathbf{2 0 0 8}$ & $\mathbf{2 0 0 9}$ & $\mathbf{2 0 1 0}$ & $\mathbf{2 0 1 1}$ & $\mathbf{2 0 1 2}$ & $\mathbf{2 0 1 3}$ & $\mathbf{2 0 1 4}$ & $\mathbf{2 0 1 5}$ & $\mathbf{2 0 1 6}$ & $\mathbf{2 0 1 7}$ \\
\hline New-build developments & 1433 & 2124 & 2521 & 1438 & 1566 & 1576 & 1658 & 1741 & 1328 & 1072 & 1051 & 1010 \\
\hline City centre & 2485 & 3678 & 4302 & 2375 & 2415 & 2459 & 2524 & 2572 & 1915 & 1522 & 1497 & 1443 \\
\hline Right bank & 1807 & 2717 & 3057 & 1567 & 1685 & 1689 & 1765 & 1854 & 1412 & 1470 & 1121 & 1081 \\
\hline Left bank & 1244 & 2589 & 2129 & 1147 & 1250 & 1276 & 1373 & 1440 & 1103 & 887 & 865 & 824 \\
\hline
\end{tabular}

Source: apartment price transaction data from SV Development (2018).

Table 1d: Nominal square metre prices for apartments in the Dniprovskii district (on the primary market), in CT (on the secondary market), and within 500 metres from the external limites of CT (on the secondary market), in conditional units (USD), 2009-2017.

\begin{tabular}{|l|c|c|c|c|c|c|c|c|c|}
\hline & $\mathbf{2 0 0 9}$ & $\mathbf{2 0 1 0}$ & $\mathbf{2 0 1 1}$ & $\mathbf{2 0 1 2}$ & $\mathbf{2 0 1 3}$ & $\mathbf{2 0 1 4}$ & $\mathbf{2 0 1 5}$ & $\mathbf{2 0 1 6}$ & $\mathbf{2 0 1 7}$ \\
\hline Dniprovskii district & 1185 & 1286 & 1318 & 1469 & 1523 & 1166 & 923 & 900 & 854 \\
\hline CT (secondary market) & - & - & - & 1529 & 1591 & 1553 & 1267 & 1278 & 1277 \\
\hline 0-500 m from CT & 1624 & 1542 & 1442 & 1444 & 1425 & 1258 & 931 & 797 & 727 \\
\hline 0-250 m from CT & 1644 & 1529 & 1447 & 1483 & 1401 & 1217 & 922 & 783 & 722 \\
\hline 250-500 m from CT & 1615 & 1547 & 1440 & 1429 & 1433 & 1273 & 934 & 801 & 729 \\
\hline
\end{tabular}

Source: Mean prices for the Dniprovskii district from SV Development (2018). Otherwise, calculated based on advertised sales prices collected from the private advertisement Aviso (2018). Both accessed 28 April 2018.

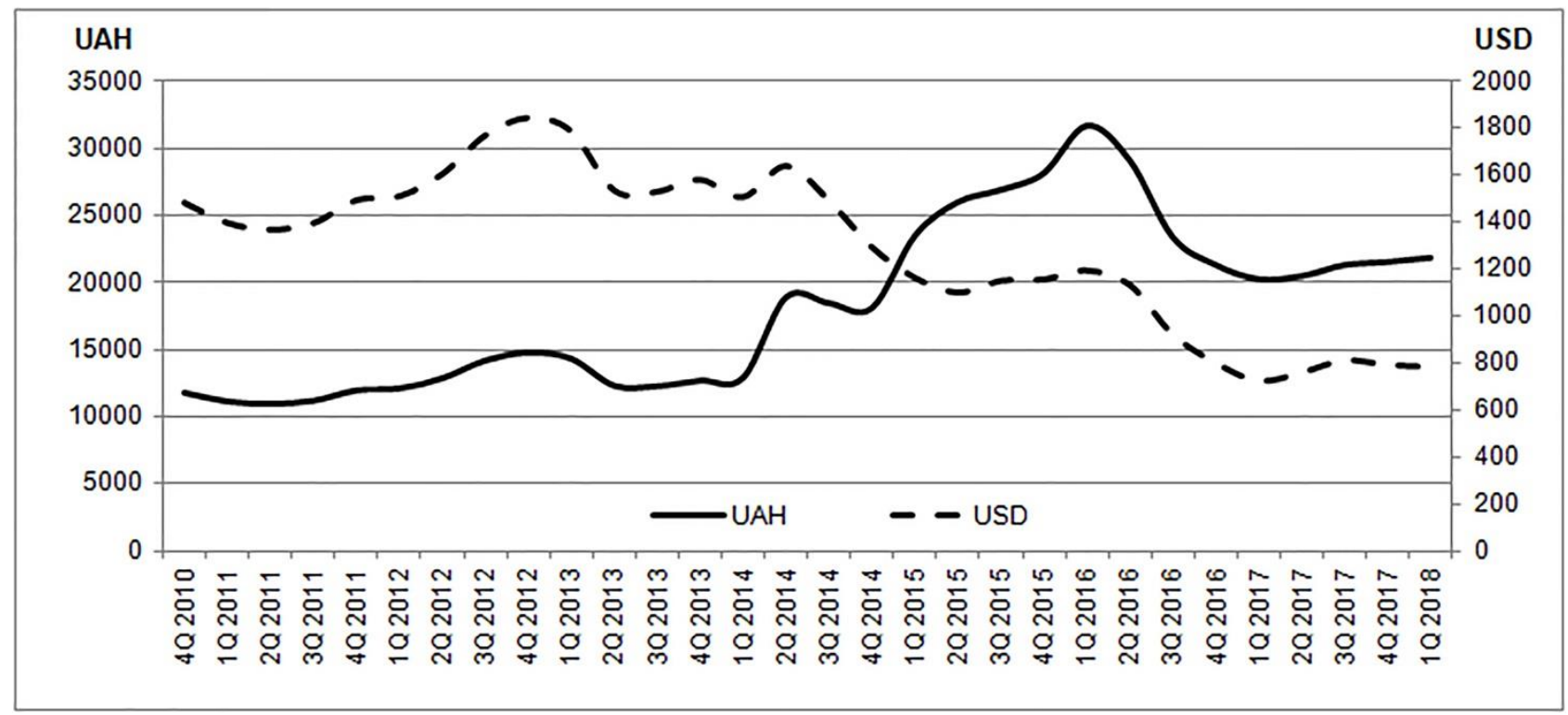

Figure 3

The market for newbuild apartments looks different in Kiev than it does in the more developed economies of Western European or North American countries. Comparing Tables 1a and 1c, it is evident that newbuild apartments are actually somewhat cheaper than apartments available on the secondary (used) market. This somewhat paradoxical situation has reasonable explanations: First of all, in an unstable context like the Ukrainian one, people are skeptical about buying property off-plan, which many perceive as "buying air" and, therefore, as a highly risky business (cf. Gentile et al. 2015). Second, the developers themselves profit from off-plan sales because they reduce the time of exposure to the risk 
associated with real estate market fluctuations (Davidson 2005, p. 497). Third, newbuild apartments in Ukraine are usually sold as unfinished objects with little (or nothing) more than the walls, windows and front door; the buyers do the rest, and it may take them months of additional work before the apartment is ready for them to settle in. Developers frequently offer much more expensive "turnkey" options as well, but at a substantial premium. "Renovated" (and turnkey) newbuilds command much higher prices than their unfinished predecessors, which is also why many people buy newbuild apartments for speculative purposes, i.e., with the intention to renovate and re-sell instantly. In short, as one would expect, a finished newbuild apartment commands much higher prices than an apartment in a Soviet-era apartment block, ceteris paribus. This is exactly the case in CT and its surroundings (Table 1d). Whereas we have not been able to calculate the exact price level of the newbuild apartments as they are supplied by the developer (no clear or reliable accessible data, but our expedition to the sales office revealed that the de facto sales prices - which the CT developer tries to keep secret - are somewhat higher than those announced in CT's ubiquitous adverts), once the apartments are re-sold on the secondary market, the current square metre price is approximately $30 \%$ higher than in the surroundings areas outside of the compound. Interestingly, CT seems to have been more resilient to the post-Maidan crisis. Before the crisis, in 2012-2013, CT apartments were sold for approximately 10-15\% more than in the Sotsgorod surroundings. In 2014, when prices dropped significantly in Sotsgorod and in the larger Dniprovskii district to which it belongs, CT managed to remain almost at the same level, with the price drop finally setting in by 2015. Thus, as a result of the crisis, the price gap between Sotsgorod and CT increased substantially. This tendency can also be observed at the macro level in Kiev, where the more attractive neighbourhoods tend to be more stable than the less attractive areas. The main reason for this is the increased gap between the purchasing power among hryvna wage earners and those who are paid in hard currency (dollars, euros). The newbuild market traditionally pertains to the domain of the latter, and is therefore more resilient to external shocks.

Having briefly examined the characteristics of the Kievan context, our paper now proceeds by presenting the results of our investigation along the CT-Sotsgorod interface. Our analysis will be 
structured along three main themes identified during the course of the fieldwork and of the analysis of the internet fora entries: (1) CT as island of civilization and "Little Europe", (2) gatedness vs "incarceration", and (3) "who cares-who dares discourses".

\section{Findings}

Our findings come from three different populations: (1) the general population of Kiev, whose views on CT frequently make their appearance in the online discussion fora, (2) the residents of CT, and (3) the residents of Sotsgorod. As we shall see, these three populations tend to emphasize different aspects and discourses.

The general population has a rather ambivalent attitude towards CT. On the one hand, the development's bright colours elicit what seems to be an inverse form of guilt by association, described by two of the online discussion forum contributors this way:

Overall - it is a [residential] complex for young and successful people with a positive attitude towards life (F50),

[...] I often look at those bright buildings!!)) Such a positive ZhK ${ }^{4}$. If I had the possibility, I would live there with pleasure (F10).

On the other hand, in discussing the virtues and drawbacks of CT, the general population's view of CT's location and of the population in the surrounding neighbourhood is relatively straightforward - and highly skeptical, as exemplified by the two following voices, which are quite representative of the sentiments we have found outside of Sotsgorod and CT:

${ }^{4} \mathrm{ZhK}$ stands for zhilishchnyi kompleks, meaning housing development or residential complex. 
This area, in my opinion - it's a depressing [forgotten] corner surrounded by old Khrushchëvki, the railway, garages. The moment you leave the territory of CT - right at the other side of the fence, you get dust and crumbling asphalt [...] and teenage proletarians hanging around with beers but no purpose, and right beside there is a buge car park with lots of stray dogs (F13).

The problem is the people living in the Khrushchëvki $i^{5}$, and not the age of the neighbourhood or of the buildings themselves. I wouldn't live there even if they paid me (F47).

For the first contributor (F13), the physical environment surrounding CT (i.e., that of Sotsgorod) is the main concern, and it is accompanied by an expected population of stray dogs and teenage proletarians. F47 identifies the residents of Sotsgorod themselves as the core problem. Thus, we may discern what appears to be constructed as a civilizational rift between what is assumed to be inside CT, and what lies outside of it. Among other things, this rift is articulated through the use of Soviet-flavoured descriptions - the teenage proletarians - in which the Soviet associations are given negative connotations. ${ }^{6}$ The rift grows even greater in the imagination and perceptions held by residents of $\mathrm{CT}$, who are likely to construe CT as a protected island of civilization, whereas outsiders are not quite as impressed. The island's rules are clearly codified - and visible upon entry to the compound thanks to a detailed list of rules and regulations pertaining to the property.

\section{Islands of civilization}

The island of civilization is possibly the strongest and most recurrent image portrayed by our informants and by the contributors to the web fora. This image is particularly sustained by the residents themselves, who often describe CT as the antithesis of its immediate surroundings, an area where Kiev's social

\footnotetext{
${ }^{5}$ Kbrushchëvka (plur. kbrusbchëvkl) is a term that is conventionally used to denote buildings erected during the first wave of mass housing construction (approximately from the late 1950s to the mid-1960s, i.e., the years of Nikita Khrushchëv's hold on power), but it is frequently used to describe any low-rise Soviet apartment block that has passed its best-before date. ${ }^{6}$ It should be noted that "Soviet" terminology is not necessarily used in a negative sense in Ukraine. Its meaning is very contextual.
} 
ailments are beyond sight, and where family life can be pursued without running the risk of encountering the outcast.

The first thing that anyone will see at their first visit [here] is the positivity of the [residential] complex. And I am not talking about the colours or the architecture, but about the atmosphere. There are no alkashi [drunkards], no babushki ["grandmothers"] sitting in front the main entrances, no homeless people rummaging in the garbage. You're just surrounded by young people, families, mothers with prams and children (F47)

The figure of the all-knowing babushki sitting on a bench (babushki na lavochke) guarding the entrance of an apartment block evokes powerful imageries of everyday life in mature Soviet neighbourhoods (Novikova 2005, Kabanova 2014), where they are central to the preservation of "neighbourhood capital". They are ubiquitous in Sotsgorod but completely absent in CT. Some people may be intimidated by their stern and supposedly judgmental gaze, but for the most part they symbolize poverty and backwardness - which the residents of CT prefer keeping out of sight. Most likely, this is why the babushki are mentioned in the same sentence as the drunkards and the homeless people: they are poor, and they belong to the past.

More than the bright colours that it is frequently associated with (there are colourful CT advertisements in most shopping malls and in many subway cars), CT promises a lifestyle that is reminiscent of low-rise American suburbia. Yet, the residents are fully aware that the idyll only stretches as far as the fences that surround the compound, a feeling elegantly summarized by one CT informant:

You go beyond the fence, and... is it Kiev? Is it the capital? It is horror! (INT K2)

Thus, outside of CT, normality vanishes, and what meets the senses is the obscenity of an urban landscape that does not live up to the slightest of metropolitan expectations. The same informant uses the example of one of the local schools (on the outside), which is used both by CT and Sotsgorod children: 
Our school has lots of kids from "Comfort". Half of the class. Our first impression about the other half is that they are miserable. Those who are from "Comfort" seem to be normal. But the others... they are miserable, suffering (INT K2).

Again, normality reigns in CT, whereas the children of the socialist city are miserable. The image of the left bank of the Dnieper, of Kiev at the other side of the river, is that of a vast working class dormitory district - a reputation earned already during the Soviet times, which is not quite as positive as the Soviet ideology would have purported.

In some cases, the island of civilization narrative evolved into a broader, at times explicit and patronizing, educative narrative. For these informants, CT stands as a success story not to be loathed but emulated:

We are showing you an example of how things can be different. Come together, organize an action group (we have such a group and we are very thank.ful). Everything is in your own hands, create an oasis of happiness for your children too! (F21)

In other words, stop whining and learn from us - and blame yourself for your current situation. CT is not only an island of civilization, but an oasis of childhood happiness, one that is carefully sanitized from antisocial behaviour such as drinking beer outdoors. One of our informants recounts that

My friends and I wanted to drink some beer on the bench outside, but the guards told us that we were not allowed to. These are the special rules of behaviour within the Comfort Town territory (INT K1).

In fact these rules are not that special, for drinking in public places is prohibited in Kiev; what is special is for the rule to be - apparently - enforced. In between the lines, the rule primarily refers to beer and spirits, which are not usually associated with "fine drinking" the way wine is - in the imagination of the 
locals beer is a Sotsgorod beverage, not a Comforttownian one (Kalyukin et al. 2015 found a similar social desirability distinction between beer and wine drinking in the regenerated Gorkii Park in Moscow).

\section{"Little Europe"}

The island of civilization narrative that emerged from the interviews went hand in hand with the idea of CT being a "European" habitat, which, in turn, was strongly influenced by the way the developers chose to package the CT product - "Your Little Europe in the Kievan Megalopolis". This is not an adjustment to the post-Euromaidan zeitgeist, but a part of a trend that had been around for a long time, starting from the so-called Evroremont ("Euro-renovation") of the 1990s which implied the improvement of Soviet-built dwellings up to (what was imagined to be) "European" standard (Seliverstova 2017). The European narrative appears to be a local incarnation of the "global" habitat produced by a constellation of supply-side stakeholders in major cities across the world (cf. Davidson 2007), yet it receives a different - and arguably stronger - degree of support from the local population, the younger part of which generally being committed to breaking with the Soviet past and to catching up with (Western) Europe:

My girlfriend used to live abroad. I chose this home on my own. When she returned, she [said she] liked Comfort Town very much. She said that she had never seen anything like it in Ukraine. That it's a European [residential] complex (INT K1).

Abroad, in this case, means Europe, which means outside of the Former Soviet Union. Of course, what it is that makes a gated estate of high-rise apartments "European" is not immediately evident. What is evident is that the area breaks with its surroundings through its spectacular aesthetics, characterized by a chromatic repertoire that has little in common with the austere colour schemes of the Soviet city. If it isn't Soviet, it must be European. However, Europe's appearance on the left bank is not welcomed by 
all. Influenced by the pervasive European narrative, one forum contributor living in Sotsgorod betrays a sense of especial antagonism and envy:

VIP's live there, and you're coming here, bothering us [as in: them]. You see, Europe is where they live (F17).

This isn't a view shared by all, however. F17's comment invited an immediate reaction in the form of:

VIP's? What VIP's? Have you seen VIP's among the mass of newcomers? They're the kids of kolkhoz directors, tax officials, cops and others, but from the provinces, since locals prefer living in better places (F27).

This reply suggests that CT is a place for outsiders, for people who are unaware of Kiev's traditional Left/Right bank division. Moreover, there is a mildly veiled insinuation that its residents stem from families whose fortunes were not made through hard labour (the professions mentioned traditionally enable lucrative illegal practices). Thus, the image of CT's residents as being homogenously middle or upple middle class is contested, and rather than being European, this contributor sees its residents as near-caricatures of the post-Soviet generation of corrupt officials.

One of the Sotsgorod informants expressed similar scepticism in relation to the actual form and function of the compound, summarizing it like this:

They tried to build a neighbourbood à la Europe, but that isn't what it is. It's something completely different. It's made our way (INT S1).

Although generally more optimistic, the insiders occasionally do express similar doubts about the quality of the ZhK's built and social environment. One informant (INT K5) compares it to life in the "dormitory named after monk Berthold Schwarz”, a reference to Ilya Ilf and Yevgeniy Petrov's 1920s' satirical novel 
12 Chairs, in which the main characters experience the downsides of the communality of a dormitory named after the monk who used to be considered the man who invented gunpowder. Nevertheless, he considers what is outside of the compound to be even worse:

Outside of the $[C T]$ territory we have a ghetto (INT K5).

\section{Gated and safe or sealed-off and incarcerated?}

Soon after the first apartments were occupied, the residents of $\mathrm{CT}$ got together to demand greater protection for "Little Europe". Before long, a semi-public space was converted into a quasi-gated one, decreasing the opportunities for contact and interaction between CT insiders and Sotsgorod outsiders. This move led to the fencing off of the property and to the hiring of $24 / 7$ security. The residents pay a voluntary monthly fee for security, and there are very few free riders. All our CT informants stressed that this measure was as an absolute necessity, and some want the security to be tightened even more (according to our own observations security is lax). Asked whether she would prefer Comfort Town to be openly accessible, one of our informants declared that

The fact that it is closed - that's a plus. A good plus. I would like to improve the security even more. [...] I would strengthen the security, the fence. To make sure that those [who come] from Hashek ["boulevard"] don't come here. I mean, if a mother and child come here, that's OK. But this way we get half of the neighbourhood. [...] No, no, no, opening the gates is out of the question. It's bad (INT K2).

In the web fora, similar opinions may be expressed even more bluntly:

I believe we have to take all possible measures towards complete isolation from the local population. I've been living bere enough, I've had enough (F22, authors' emphasis). 
$100 \%$, we don't need your company on [sic!'] our hood)))) go and hang around your filthy courtyards [...] and if all the scum from the hood comes here, we'll end up the same))) we're going to continue paying for security (F35).

Of course, web fora are known for attracting polarized and provocative statements. However, the main message that we identified not only in the fora but also in our interviews within CT is that the insiders feel relatively unrestrained in describing their desire and perceived need to shut off Sotsgorod, heightening the inevitable sense of insularity that comes with living in a (quasi-)gated compound on a former brownfield surrounded by decaying Soviet Khrushchëv- and Brezhnev-era buildings. For the CT residents, Sotsgorod is an existential threat, and all plausible measures should be taken to defend the compound from its negative influence. For them, CT is gated and safe, although perhaps not as much as desired.

The gatedness of CT should be interpreted in the light of the lifestyle associated with CT, which is not the one regularly associated with centrally located newbuild projects built on former brownfields. Instead, it is more reminiscent of the secluded "Docklands suburbia" identified by Tim Butler (2007), but with one major modification: whereas the Docklands newbuild gentrifiers live within easy access of their workplaces (the City and the Docklands themselves), their CT counterparts are car-dependent and may face long home-to-work commutes, which was a fairly recurrent theme in our interviews, and stands in strong contrast with one of CT's selling points, i.e., its relatively central location. One of our informants from Sotsgorod clarified this point most unambiguously:

The people from Comfort Town don't come here [to Sotsgorod]. They have their own supermarket and they all have cars (INT S1).

\footnotetext{
${ }^{7}$ In Russian: "na nashem rayone". The preposition "na", rather than "v", before "rayon" is slang of a kind that is often associated with a lower level of education.
} 
Among the residents of Sotsgorod, whom many CT residents appear to look down at, CT is perceived more as a form of voluntary incarceration than as a safe haven. One informant recounts her one and only experience at the main gates of $\mathrm{CT}$ :

I once had to visit Comfort Town [...] And the guard didn't let me in. He said: you can't come in here. And I asked him: so what is this, a special zone [as in: jail]? Are you prisoners? Is this a closed-off zone with special environmental factors? (INT S2)

The "special environmental factors" refer to the environmentally hazardous activities of the demised "Vulkan" factory. Indeed, the environmental theme often came up in discussions with Sotsgorod residents who, unlike the "outsiders", know the area either through personal experience or through local hearsay. We will return to this theme below.

In addition to the dual gating-incarceration narrative, the associated idea that its residents are not "genuine" Kievans is one that we have encountered on various occasions, and is nitidly expressed in the words of informant S2:

If the residents of "Comfort Town" fence themselves off from the Kievans, well, in that case, it's a settlement for outsiders (INT S2).

This statement succinctly captures the essence of Sonia Hirt's (2012) concept of spatial secession exemplified by the creation of breakaway neighbourhoods (gated communities) that are voluntarily sealed off from the surroundings. However, there is one more dimension at play here, and that refers to what being a real Kievan actually means. As illustrated in some of the interview excerpts presented above, CT is sometimes understood as something that does not belong where it is, with a population that does not 
belong on the left bank (or either) side of the Dnieper. Moreover, this population may become more alien to its surroundings - and not less - over time:

I think that the people who are educated there, that go to school or to kindergarten there, well, roughly speaking, they just fall out of society. They live within a closed territory, everything is cool there, everything is super, but the moment they leave their fenced off area, they find drug addicts, prostitutes [...] Kids should be able to realize it, and they should somehow be able to deal with it, to understand what is right and what is wrong (INT S3)

For this informant, despite some ambiguity, CT does not prepare its children for the hardships of the Kievan street, and it prevents them from socializing them properly. Growing up in CT, in this view, would mean growing up in disjunction from Kiev and, in particular from the Left Bank. What is certain, however, is that growing up in CT means growing up in an area of uncertain environmental status. It is, after all, a former brownfield site that has only been subject to partial sanitization; in particular, soil replacement did not take place in the numerous areas that contained full-grown trees, presumably because doing so would have undermined one of the main sales arguments (parks) of the complex. We now turn to the final main narrative that we identified in our interview materials, which has to do with the environmental situation in CT.

\section{Brownfield blues: who cares, who dares?}

Everything is fine. When they built the complex, they removed the top layer of soil. They say that someone came to check the level of contamination (INT K1).

Yes, yes, yes... This is how it is: so they built [CT] on the territory of the factory, so they did it. It hasn't influenced our bealth. Many say that there used to be a factory. But we don't care (INT K2). 
Informants $\mathrm{K} 1$ and $\mathrm{K} 2$ represent the most frequently encountered attitude towards the potential environmental hazards of living in CT: ignoring the elephant in the room. There are three probable main reasons for this: first, many buyers were convinced about or chose to believe in the quality of the sanitization process, and do not see this as a problem. Second, some are presumably de-sensitized to the issue, well aware of the fact that environmental degradation is a problem occurring throughout the city. Third, some buyers were simply unaware of the compound's industrial past:

We found out [about this] when we moved here. But we decided that we wouldn't be bothered. We closed our eyes. Nowadays it's hard to find a place to live which is relatively close to the centre and in an environmentally clean area (INT K3).

Informant K3's reaction is thus one of accepting the fact that CT is not quite as expected, and that there would have been few alternatives anyway. However, the opinions about the actual environmental situation differ substantially, most notably between CT insiders and Sotsgorod outsiders. One of the latter describes how "Europe" comes with a catch:

The apartments are of European quality. And they are cheap. But it is so polluted there, and it all went into the soil. Nothing [no soil] was removed. They just added some. And what if monsters will be born there? It's just horrible! [...] Yes, it is a nice settlement. Yes, it is beautiful. Really nice. But it is so polluted, there is radiation, heavy metals. I feel sorry for those who buy apartments there. [...] I feel sorry for the kids, the young mothers. We tried to warn people, but no one listened. It's like living in Chernobyl (INT S2).

While the reductio ad Chernobylem clearly is an exaggeration - radiation is not a concern in CT - this informant reminds us of the nuclear accident's central position in Ukrainian collective memory. Informant S2 contrasts the superficial cleanliness and Europeanness of CT with the invisible hazards that do not catch the eye, implying that the opposite holds true in Sotsgorod, i.e., that it is a messy Soviet neighbourhood, but without toxic skeletons in its closet. CT and Sotsgorod are thus, and again, perceived 
as each other's opposites. In fact, in the environmental sense they are not all that different: both have among the highest levels of air pollution in the city (Cityscale.com.ua 2018).

\section{Conclusions: the newbuild archipelago}

NBG in Kiev shares some commonalities with comparable processes across Europe: it has a striking visible impact on the areas influenced by it, and, numerically speaking, it alters the social class structure of the population enumeration districts touched by it. There are, however, several important differences, discussed below, that help shed light on the variegated nature of this globalizing process.

Summing up our main findings, we find resonance in Brian Berry's (1985) well-rehearsed gentrification analogy, but with an additional twist: Kiev's largest newbuild compound is an island of prosperity in a sea of decay, but it is also an island within an archipelago of indifference, marked by hard rocky cliffs and rugged shorelines. Our study reveals a striking lack of contact and understanding between the residents of CT - the newbuild gentrifiers - and their socialist city neighbours. CT appears to have little more effect on its surroundings than the purely visual one: it has its own stores, cafés and parking facilities, but the high pricing of its on-site private schools means that many of its younger residents are consumers of Sotsgorod's educational facilities. Other than that, it appears to live and function as a somewhat porous suburban fenced estate, rather than as a typical newbuild development of the kind described in the burgeoning literature within the field. In this sense, it is similar to the Docklands' newbuilds discussed by Butler (2007), if only at a superficial level: the residents of CT experience greater physical distance to their workplaces, but lesser social distance to their neighbours, than do the newbuild gentrifiers of the Docklands. Even so, CT residents lead a segregated and sealed-off existence on Kiev's "East Side", in a settlement that can be characterized, to recycle Atkinson's (2006) metaphor, as a colourful "padded bunker", a bunker whose striking yet simple aesthetics engage with an idealized "Europe" defined, in part, by the obsolescence of its (Soviet/socialist) surroundings. Indeed, the "Little Europe" product packaging that we observed echoes Davidson's $(2007,2008)$ observation that social distinction is tailored by the architects, developers and planners, rather than being the result of demand- 
side forces. Of course, the Euro-narrative is neither unique nor novel, but rather refers to a powerful discourse that reaches back to the early years of independence, when Soviet apartments were "Eurorenovated" by those who were able to afford the investment. As a result, in contemporary Ukraine, "European" is for local developers what "global" means for those based in London or New York, it is a concept that lies at the core of their quest to produce a special brand of social distinction that unrepentantly Others the existing urban fabric, and its residents, as Soviet laggards. Put differently, newbuild gentrification in Kiev may well lead to islands of prosperity in a sea of decay, but these islands are being discursively framed as islands of civilization in a sea of delay, as colourful beacons of Europeanness towering out of the dark anachronism of the Soviet city.

Despite seemingly moderate social differences, social mixing does not appear to be taking place, nor does anyone appear to be expecting or even wanting it to take place. And in this there lies a certain paradox, for in a context where social mixing and low levels of residential segregation have been the rule for decades, there seems to be little response when the arrival of a pseudo-gated mastodont upsets this balance. Why gatedness in Kiev is met with such little interest or resistance would be a topic for further research, but there are certain contextual characteristics that might provide a partial explanation. First, as a rule, new residential construction projects deliver a final product that is not accessible to the public, with very few exceptions. What differs is the scale of the projects, from the individual infill with sealed-off courtyards to the multi-block fenced and gated condominium; in this sense, Comfort Town is nothing more than a huge condominium - large enough to sustain a couple of its own cafés and a striking number of beauty parlours and pharmacies. Second, Soviet cities, Kiev included, were scarred by large swathes of urban land that was fenced off, closed or even secret, mainly for industrial or military purposes (industrial land use accounted for very high shares of total urban land use in socialist cities, see Bertaud 2006). Likewise, the work of the city architect bureau used to be secret, and urban planning was not subject to any public scrutiny whatsoever. In other words, for many of Sotsgorod's residents, CT may be less of a novelty (beyond the colour palette used), and more of a déjà$v u$ than what one might be led to think. 
Thus, while the residents of CT and Sotsgorod may hold strong opinions about one another - class stereotypes, basically- they also appear to be indifferent to each other's presence. This indifference is not easily placed within the extant literature on the social consequences of gentrification at the neighbourhood level. What appears to matter the most is the extent to which CT's newbuild gentrifiers and their Sotsgorodite neighbours live completely segregated lives. Comforttowners seem to avoid Sotsgorod at any cost (except when they have no choice), while simultaneously hoping that none of its residents enter the compound, but the latter don't seem to be bothered by this, as they appear to expect and accept this behaviour as normal. Moreover, there appears to be no price shadowing or gentrification spillover effect on the surroundings whatsoever, although it would be difficult to spot such an effect amidst a rollercoaster housing market such as that of Kiev. As a result, many of the assumed negative effects of NBG on the living conditions in Sotsgorod are simply absent: Because of the predominance of owner occupation, direct displacement does not occur, and indirect displacement does not even emerge as a phenomenological condition of gradual gentrification-induced placeunmaking. And why is this so? One possibility is that, despite everything, the Sotsgorod residents have experienced more dramatic changes in their neighbourhood in the past as a result of the marketization of retailing, which slashed their purchasing power and transformed their streets into an unrestrained consumerist spectacle to the benefit of the few. More importantly, any discomfort associated with the appearance of Comfort Town fades when compared with the dramatic drop in quality of life and purchasing power experienced by the vast majority since the early 1990s. This leads to the suggestion that the social and community consequences of newbuild gentrification are highly contextual, and "compete" for the interest of those influenced by the process. Thus, unlike Davidson (2010), who warns against "benign diagnosis" (p. 541) based on the suggestion that "the absence of many modes of social mixing in gentrifying neighbourhoods is constitutive of processes which actively structure class difference" (ibid.), our position is more agnostic. Indeed, CT would probably exert a greater influence on the lives of those living in its surroundings if it functioned as more than a bedroom community, i.e., if it were not as segregated as it is. As it is today, for the long-term residents of Sotsgorod, CT is a 
hostile, unfamiliar and scarcely relevant "rainbow-field". In at least one sense, however, this is an improvement, for the residents are no longer exposed to the noxious emissions produced by rubber recycling, nor do they have to contend with living next to a blighted brownfield. As a matter of fact, while indifference and insularity characterize the social contacts that are (not) evolving between newcomers and long-term residents, none of the opinions expressed by any of our sources suggested a longing for the past.

Finally, it is worth noting that CT and Sotsgorod are not just socially distinct, but also demographically. CT is a young neighbourhood inhabited by members of the lower and mid-middle classes. Unlike the generation of their parents, this group was not able to benefit from the wholesale housing privatization process of the early 1990s. Low wages or pensions lock Sotsgorod's working class in their own dwellings, but their housing expenses are nevertheless low and relatively predictable. Conversely, CT's new middle class is dependent on higher real wages - either their own or their parents' - and this is a far more unstable form of wealth given the volatility of the Ukrainian economy. The fact that housing opportunities appear for this young group also relieves some pressure from the older cohorts, who frequently live(d) in multi-generation households. The ageing Sotgorodite working class, as far as we have been able to see, is not being displaced, or even displaced, but it is certainly experiencing a significant transformation of its habitat and, not least, a significant degree of developerled stigma implanted in the Little Europe narrative, which portrays a young, bright and civilized rainbow-field rising out of the gray sea of Soviet obsolescence.

\section{References}

Andersen, B., \& Røe, P. G. (2016). The social context and politics of large scale urban architecture: Investigating the design of Barcode, Oslo. European Urban and Regional Studies, doi: 0969776416643751.

Anguelovski, I. (2015). Healthy food stores, greenlining and food gentrification: contesting new forms of privilege, displacement and locally unwanted land uses in racially mixed neighborhoods. International Journal of Urban and Regional Research 39 (6), 1209-1230. 
Atkinson, R. (2000). Measuring gentrification and displacement in Greater London. Urban Studies, 37(1), 149-165.

Atkinson, R. (2006). Padding the bunker: strategies of middle-class disaffiliation and colonisation in the city. Urban Studies, 43(4), 819-832.

Aviso (2016), private advertisement website. Available online at http://www.aviso.ua/kiev/list.php (last accessed 28 April 2018).

Bernt, M. (2016). How post-socialist is gentrification? Observations in East-Berlin and Saint Petersburg. Eurasian Geography and Economics 57 (4-5): 565-587.

Bernt, M., Gentile, M., and Marcińczak, S. (2015). Gentrification in post-communist countries: An introduction. Geografie 120(2): 104-112.

Berry, B. (1985). "Islands of Renewal in Seas of Decay.” In The New Urban Reality, edited by P. Peterson, 69-96. Washington, DC: Brookings.

Bertaud, A. (2006). "The spatial structures of Central and Eastern European cities." In The urban mosaic of post-socialist Europe, edited by S. Tsenkova and Z. Nedović-Budić, 91-110. Heidelberg, Germany: Physica-Verlag.

Boddy, M. (2007). Designer neighbourhoods: new-build residential development in nonmetropolitan UK cities-the case of Bristol. Environment and Planning A, 39(1), 86-105.

Boterman, W. R., Karsten, L., and Musterd, S. (2010). Gentrifiers settling down? Patterns and trends of residential location of middle-class families in Amsterdam. Housing Studies, 25(5), 693-714.

Bounds, M., and Morris, A. (2006). Second wave gentrification in inner-city Sydney. Cities, 23(2), 99-108.

Bridge, G. (2006). It's not just a question of taste: gentrification, the neighbourhood, and cultural capital. Environment and Planning A, 38(10), 1965-1978.

Bryson, J. (2013). The nature of gentrification. Geography Compass, 7(8), 578-587.

Butler, T. (2007). Re-urbanizing London Docklands: Gentrification, Suburbanization or New Urbanism? International Journal of Urban and Regional Research, 31(4), 759-781.

Butler, T. and Robson, G. (2003). London Calling: The Middle Classes and the Remaking of Inner London. Oxford and New York: Berg.

Buzar, S., Hall, R., and Ogden, P. (2007). Beyond gentrification: the demographic reurbanisation of Bologna. Environment and Planning A, 39(1), 64-85.

Cartier, C. (2017), Contextual urban theory and the 'appeal' of gentrification: lost in transposition? International Journal fo Urban and Regonal Research 41(3): 466-477.

Cheshire, P. (2006). Resurgent cities, urban myths and policy hubris: what we need to know. Urban Studies, 43(8), 1231-1246. 
Choi, N. (2016). Metro Manila through the gentrification lens: Disparities in urban planning and displacement risks. Urban Studies, 53(3), 577-592.

Cityscale.com.ua (2018), Karta istochnikov ragryazneniya [Map of the sources of pollution], online database available at http://www.cityscale.com.ua/index.htm?data=polutsrcs\&region=kiev-levyy-bereg (accessed 1 May 2018).

Comfort Town (2018), O komplekse [About the complex], http://comforttown.com.ua/ru/about (accessed 4 April 2018).

Dangschat, J. (1988). “Gentrification: Der Wandel innenstadtnaher Wohnviertel.” In Soziologische Stadtforschung, edited by J. Friedrichs, 272-292. Cologne, Germany: Westdeutsche Verlag.

Davidson, M. (2007). Gentrification as global habitat: a process of class formation or corporate creation?. Transactions of the Institute of British Geographers, 32(4), 490-506.

Davidson, M. (2008). Spoiled mixture: where does state-ledpositive'gentrification end?. Urban Studies, 45(12), $2385-2405$.

Davidson, M. (2010). Love thy neighbour? Social mixing in London's gentrification frontiers. Environment and Planning A, 42(3), 524-544.

Davidson, M. (2018), New-build gentrification. In Handbook of Gentrification Studies, edited by L. Lees and M. Phillips, $247-261$. Cheltenham, UK, and Northampton, Mass., USA: Edward Elgar.

Davidson, M., and Lees, L. (2005). New-build 'gentrification'and London's riverside renaissance. Environment and Planning A, 37(7), 1165-1190.

Davidson, M., and Lees, L. (2010). New-build gentrification: its histories, trajectories, and critical geographies. Population, Space and Place, 16(5), 395-411.

Davis, L. (2011). International events and mass evictions: A longer view. International Journal of Urban and Regional Research, 35(3), 582-599.

Derzhavna Sluzhba Statystyky Ukrayiny (2017), Srednyaya zarabotnaya plata po regionam [Mean wages by region] www.ukrstat.gov.ua (accessed 3 June).

Domik.ua (2018). Statistika i dinamika tsen na nedvizhimost' [Real estate price statistics and dynamics]. Electronic database available at http://domik.ua/nedvizhimost/dinamika-cen.html (accessed 27 April 2018).

Doucet, B. (2009). Living through gentrification: subjective experiences of local, non-gentrifying residents in Leith, Edinburgh. Journal of Housing and the Built Environment, 24(3), 299-315.

Doucet, B., van Kempen, R., and van Weesep, J. (2011). 'We're a rich city with poor people': municipal strategies of new-build gentrification in Rotterdam and Glasgow. Environment and Planning A, 43(6), 1438-1454.

Dutton, P. (2003). Leeds calling: the influence of London on the gentrification of regional cities. Urban Studies, 40(12), 25572572 .

Florida, R. (2003). Cities and the creative class. City \& Community, 2(1), 3-19. 
Freeman, L. (2006). There Goes the Hood: Views of Gentrification from the Grounds Up. Philadelphia: Temple University Press.

Freeman, L. (2008). Comment on 'The eviction of critical perspectives from gentrification research'. International Journal of Urban and Regional Research, 32(1), 186-191.

Freeman, L., and Braconi, F. (2004). Gentrification and displacement New York City in the 1990s. Journal of the American Planning Association, 70(1), 39-52.

Gaffney, C. (2016), Gentrifications in pre-Olympic Rio de Janeiro, Urban Geography, 37(8), 1132-1153.

Galitskaya, O. (2013), Ipoteka pomerla. Khay zhive rostrochka: chim vidriznyayetsya rostrochka vid ipoteki [Mortgage is dead. Long live the installment: the difference between installments and mortgage], Kontrakty.ua, 1 April, available at http://kontrakty.ua/article/60368 (accessed 2 June 2017).

Gentile, M., and Sjöberg, Ö. (2006). Intra-urban landscapes of priority: the Soviet legacy. Europe-Asia Studies, 58(5), 701-729.

Gentile, M., and Sjöberg, Ö. (2013). Housing allocation under socialism: The Soviet case revisited. Post-Soviet Affairs, 29(2), 173-195.

Gentile, M., Salukvadze, J., and Gogishvili, D. (2015). Newbuild gentrification, teleurbanization and urban growth: placing the cities of the post-Communist South in the gentrification debate. Geografie, 120(2), 134-163.

Ghertner, D. A. (2015). Why gentrification theory fails in 'much of the world'. City, 19(4), 552-563.

Goodfellow, T. (2017). Urban fortunes and skeleton cityscapes: real estate and late urbanization in Kigali and Addis Ababa. International Journal of Urban and Regional Research, 41(5), 786-803.

Grabkowska, M. (2015). Between gentrification and reurbanisation: The participatory dimension of bottom-up regeneration in Gdańsk, Poland. Geografie, 120(2), 210-225.

Haase, A., Grossmann, K., \& Steinführer, A. (2012). Transitory urbanites: New actors of residential change in Polish and Czech inner cities. Cities, 29(5), 318-326.

Haase A, Steinführer A, Kabisch S, Buzar S, Hall R, Ogden P, (2010). Emergent spaces of reurbanisation: exploring the demographic dimension of inner-city residential change in a European setting. Population, Space and Place 5: 443-463.

Hamnett, C. (2009). The new Mikado? Tom Slater, gentrification and displacement. City, 13(4), 476-482.

Harris, A. (2008). From London to Mumbai and back again: gentrification and public policy in comparative perspective. Urban Studies, 45(12), 2407-2428.

Hiob, M., Nutt, N., Nurme, S., and De Luca, F. (2012). Risen from the dead: from slumming to gentrification. Transylvanian Review of Administrative Sciences $36 \mathrm{E} / 2012,92-105$.

Hirt, S. (2012). Iron Curtains: Gates, Suburbs and Privatization of Space in the Post-socialist City. Chichester, UK: John Wiley \& Sons. Hochstenbach, C., Musterd, S., \& Teernstra, A. (2015). Gentrification in Amsterdam: Assessing the importance of context. Population, Space and Place, 21(8), 754-770. 
Holm, A., Marcińczak, S., and Ogrodowczyk, A. (2015). New-build gentrification in the post-socialist city: Lodź and Leipzig two decades after socialism. Geografie, 120(2), 164-187.

Hyra, D. (2015). The back-to-the-city movement: Neighbourhood redevelopment and processes of political and cultural displacement. Urban Studies 52(10): 1753-1773.

Jowett, A. (2015). A case for using online discussion forums in critical psychological research. Qualitative Research in Psychology, $12(3), 287-297$.

Kabanova, A. (2014), Principy organizatsii vkhodnoy zony v pod'ezd mnogokvartirnogo zhilogo doma [The principles of the organization of the entry zone of multi-apartment buildings], in O. Kraev (ed.), Molodez̧h i nauka: sbornik materialov X yubileynoy userossiyskoy nauchno-tekhnicheskoy konferentsii studentov, aspirantov i molodykh uchënykh s mezhdunardonym uchastiem, posvyashchennot 80-letiyu obrazovaniya Krasnoyarskogo kraya (Krasnoyarsk: Siberian Federal University), electronic document available at conf.sfu-kras.ru/sites/mn2014/pdf/d03/s44/s44_005.pdf (accessed 4 April 2018).

Kalyukin, A., Borén, T., and Byerley, A. (2015). The second generation of post-socialist change: Gorky Park and public space in Moscow. Urban geography, 36(5), 674-695.

Kleinhans, R. (2004). Social implications of housing diversification in urban renewal: A review of recent literature. Journal of Housing and the Built Environment, 19(4), 367-390.

Kovács, Z., Wiessner, R., Zischner, R. (2013). Urban renewal in the inner city of Budapest: Gentrification from a post-socialist perspective. Urban Studies, 50(1), 22-38.

Lees, L. (2008). Gentrification and social mixing: towards an inclusive urban renaissance? Urban Studies, 45(12), 2449-2470.

Lees, L., Shin, H. B., and López-Morales, E. (2016). Planetary Gentrification. Chichester: John Wiley \& Sons.

Lemanski, C. (2006). Spaces of exclusivity or connection? Linkages between a gated community and its poorer neighbour in a Cape Town master plan development. Urban Studies, 43(2), 397-420.

Lemanski, C. (2014). Hybrid gentrification in South Africa: Theorising across southern and northern cities. Urban Studies, 51(14), 2943-2960.

Lilius, J. (2014). Is there room for families in the inner city? Life-stage blenders challenging planning. Housing Studies, 29(6), 843-861.

López-Morales, E. (2015), Gentrification in the Global South, City 19 (4): 564-573.

LUN (2018), Novostroiki Kieva [Newbuilds in Kiev], web resource available at https://novostroyki.lun.иа/жк-комфорттаун-киев (accessed 3 April).

Marquardt, N., Füller, H., Glasze, G., and Pütz, R. (2012). Shaping th urban renaissance: New-build luxury developments in Berlin. Urban Studies 50(8): 1540-1556. 
Mills, C. A. (1988). "Life on the upslope": the postmodern landscape of gentrification. Environment and Planning D: Society and Space, 6(2), 169-190.

Murphy, L. (2008). Third-wave gentrification in New Zealand: the case of Auckland. Urban Studies, 45(12), 2521-2540.

Nagy, E., and Timár, J. (2012). Urban restructuring in the grip of capital and politics: Gentrification in East-Central Europe. In Development of the Settlement Network in the Central European Countries, edited by Tamás Csapó and András Balogh, 121 135. Berlin and Heidelberg: Springer.

Novikova, I. (2005). Babushka in Riga - age and power in Russian-speaking translocal contexts. Sociologija - Mintis ir Veiksmas 2005(1), 82-95.

Orlova, D. (2017). 'Europe' as a normative model in the mediatised discourse of Ukrainian political elites. Europe-Asia Studies 69(2), 222-241.

Osipova, L. (2013), Zhitlo v rozstrochku: Top-10 rozstrochok vid zabudovnykiv i spil'nykh program kredutovannya [Housing in installments: Top-10 installments from developers and joint credit programs], Kontrakty.ua, 24 April, available at http://kontrakty.ua/article/61463 (accessed 2 June 2017).

Rérat, P. (2012a). Gentrifiers and their choice of housing: characteristics of the households living in new developments in Swiss cities. Environment and Planning A, 44(1), 221-236.

Rérat, P. (2012b). Choix résidentiel et gentrification dans une ville moyenne. Cybergeo: European Journal of Geography, Espace, Société, Territoire, document 579, 19, available online at http://cybergeo.revues.org/24931 [accessed 29 November 2016].

Rérat, P., Söderström, O., Piguet, E., and Besson, R. (2010). From urban wastelands to new-build gentrification: The case of Swiss cities. Population, Space and Place, 16(5), 429-442.

Rose, D. (1984). Rethinking gentrification: beyond the uneven development of Marxist urban theory. Environment and Planning $D, 2(1), 47-74$.

Rose, D. (2010). Local state policy and 'new-build gentrification'in Montréal: the role of the 'population factor'in a fragmented governance context. Population, Space and Place, 16(5), 413-428.

Robinson, J. (2011). Cities in a world of cities: the comparative gesture. International Journal of Urban and Regional Research, 35(1), $1-23$.

Rösner, L., and Krämer, N. (2016). Verbal venting in the social web: Effects of anonymity and group norms on aggressive language use in online comments. Pre-published online in Social Media+Society, 2(3), 2056305116664220.

Sagan, I., and Grabkowska, M. (2013). "Negotiating Participatory regeneration in the post-socialist inner city." In The Routledge Companion to Urban Regeneration, edited by M. Leary and J. McCarthy, 433-442. London and New York: Blackwell. 
Sage, J., Smith, D., and Hubbard, P. (2012). The rapidity of studentification and population change: there goes the (student) hood. Population, Space and Place, 18(5), 597-613.

Seliverstova, O. (2017), Keeping alive the "Imaginary West" in post-Soviet countries, Journal of Contemporary Central and Eastern Europe 25(1): 117-134.

Shin, H. (2016). Economic transition and speculative urbanisation in China: Gentrification versus dispossession. Urban Studies, 53(3), 471-489.

Shin, H., and Kim, S. (2016). The developmental state, speculative urbanisation and the politics of displacement in gentrifying Seoul. Urban Studies, 53(3), 540-559.

Sigler, T., and Wachsmuth, D. (2016). Transnational gentrification: Globalisation and neighbourhood change in Panama's Casco Antiguo. Urban Studies, 53(4), 705-722.

Slater, T. (2006). The eviction of critical perspectives from gentrification research. International Journal of Urban and Regional Research, 30(4), 737-757.

Slater, T. (2009). Missing Marcuse: On gentrification and displacement. City, 13(2-3), 292-311.

Slater, T. (2017). Planetary rent gaps. Antipode, 49(S1), 114-137.

Smart, A., and Smart, J. (2017). Ain't Talkin'Bout Gentrification: The Erasure of Alternative Idioms of Displacement Resulting from Anglo-American Academic Hegemony. International Journal of Urban and Regional Research, 41(3), 518525.

Smith, D., and Holt, L. (2007). Studentification and 'apprentice'gentrifiers within Britain's provincial towns and cities: extending the meaning of gentrification. Environment and Planning A, 39(1), 142-161.

Smith, D. P., and Hubbard, P. (2014). The segregation of educated youth and dynamic geographies of studentification. Area, 46(1), 92-100.

Smith, N. (1996). The New Urban Frontier: Gentrification and the Revanchist City. London and New York: Routledge.

Smith, N. (2002). New globalism, new urbanism: gentrification as global urban strategy. Antipode, 34(3), 427-450.

Stabrowski, F. (2014). New-Build Gentrification and the Everyday Displacement of Polish Immigrant Tenants in Greenpoint, Brooklyn. Antipode, 46(3), 794-815.

SV Development (2018), electronic resource on the real estate market in Kiev, available at http://www.svdevelopment.com/ua/web/flat_costs/ (accessed 28 April 2018).

Sýkora, L. (2005). "Gentrification in post-communist cities". In Gentrification in a global context, edited by R. Atkinson and G. Bridge, 91-105. London and New York: Routledge.

Temelová, J. (2007). Flagship developments and the physical upgrading of the post-socialist inner city: the Golden Angel project in Prague. Geografiska Annaler: Series B, Human Geography, 89(2), 169-181. 
Temelová, J., \& Dvořáková, N. (2012). Residential satisfaction of elderly in the city centre: The case of revitalizing neighbourhoods in Prague. Cities, 29(5), 310-317.

Tolsma, J., van der Meer, T., and Gesthuizen, M. (2009). The impact of neighbourhood and municipality characteristics on social cohesion in the Netherlands. Acta Politica, 44(3), 286-313.

Uitermark, J., Duyvendak, J. W., \& Kleinhans, R. (2007). Gentrification as a governmental strategy: social control and social cohesion in Hoogvliet, Rotterdam. Environment and Planning A, 39(1), 125-141.

Valiyev, A. (2013). Baku. Cities 31(April): 625-640.

Van Criekingen, M., and Decroly, J. M. (2003). Revisiting the diversity of gentrification: neighbourhood renewal processes in Brussels and Montreal. Urban Studies, 40(12), 2451-2468.

Van Kempen, R., and Bolt, G. (2009). Social cohesion, social mix, and urban policies in the Netherlands. Journal of Housing and the Built Environment, 24(4), 457-475.

Visser, G. and Kotze, N. (2008). The state and new-build gentrification in central Cape Town, South Africa. Urban Studies 45(12): 2565-2593.

Wacquant, L. (2008). Relocating gentrification: the working class, science and the state in recent urban research. International Journal of Urban and Regional Research, 32(1), 198-205.

Zavisca, J. (2012), Housing the New Russia (Ithaca, NY: Cornell University Press).

\section{Interviews cited in text}

K1: M, 30, single, no children, higher ed, interviewed by Gentile, Mezentsev and Mezentseva.

K2: F, 34, 1 child, higher ed, married, interviewed by Mezentseva.

K3: F, 25, higher ed, 2 small children, married, interviewed by Mezentseva and Stebletska.

K4: M, 36, higher ed, 1 small child, divorced, interviewed by Mezentseva and Stebletska.

K5: M, 40, higher ed, 2 children, divorced, interviewed by Stebletska.

S1: M, 30, higher ed, married, no kids, interviewed by Mezentseava.

S2: F, 57, higher ed., married, three grown-up children, lives in curent dwelling since 1962, interviewed by Mezentseva and Stebletska.

S3: M, 25, incomplete higher ed, single, no children, interviewed by Stebletska. 
